\title{
KORELASI ANTARA KONSUMSI KOPI DENGAN TEKANAN DAN GULA DARAH, IMT, Hb, LAMA TIDUR DAN SCREEN TIME BARISTA DI KABUPATEN MAJALENGKA TAHUN 2021
}

\author{
Hafidz Hilal Assegaf, Susianto Susianto Tseng, Mamlukah \\ STIKes Kuningan \\ hafiz.assegaf5@gmail.com
}

\begin{abstract}
Abstrak
Budaya minum kopi menjadi salah satu budaya paling popular dan digemari masyarakat. Kebiasaan minum kopi berkorelasi dengan berbagai masalah kesehatan, baik yang menguntungkan maupun merugikan. Barista terkait dalam pekerjaannya memiliki peluang untuk lebih banyak meminum kopi dalam berbagai sajian sehingga dikhawatirkan memberikan dampak pada status kesehatannya. Tujuan penelitian ini untuk menganalisis korelasi antara konsumsi kopi dengan tekanan dan gula darah, IMT, Hb, lama tidur dan screen time barista di Kabupaten Majalengka. Penelitian ini menggunakan desain cross-sectional. Sebanyak 40 barista di Majalengka terlibat dalam penelitian ini menggunakan total sampling. Instrumen yang digunakan adalah kuesioner, pengambilan darah dan pengukuran indeks massa tubuh. Data dianalisis menggunakan Rank Spearman dan Regresi Logistik Berganda. Responden ratarata meminum kopi sebanyak 4 gelas perhari, memiliki tekanan darah sistolik $117 \mathrm{mmHg}$, diastolik 77,75 mmHg, kadar gula darah sebesar 115,5 mg/dl dan kadar Hemoglobin 13,8 $\mathrm{mg} / \mathrm{dl}$. Semua responden memiliki status gizi baik, waktu tidur yang cukup $(8,74 \mathrm{jam})$, dan screen time yang berlebih $(8,1 \mathrm{jam})$. Lama tidur berkorelasi negatif dengan konsumsi kopi $(\mathrm{p}=0,012)$ dengan koefisien korelasi sebesar -0,395 (kekuatan hubungan sedang). Konsumsi kopi tidak berkorelasi dengan tekanan darah $(p=0,168)$, gula darah $(p=0,257), \operatorname{IMT}(p=0,251)$, kadar $\mathrm{Hb}(\mathrm{p}=0,93)$ dan screen time $(\mathrm{p}=0,899)$. Konsumsi kopi berkorelasi dengan lama tidur setelah dikontrol dengan tekanan darah, gula darah, dan indeks massa tubuh barista $(\mathrm{p}=0,009)$. Konsumsi kopi mempengaruhi lama tidur yang dikontrol dengan variabel tekanan darah, kadar gula darah dan indeks massa tubuh barista di Kabupaten Majalengka. Perlunya promosi tentang pola konsumsi dan dampak kesehatan terhadap barista dan pemilik kafe di Kabupaten Majalengka.
\end{abstract}

Kata kunci : barista, darah, kopi, lama tidur, screen time

\section{Pendahuluan}

Budaya minum kopi menjadi salah

satu budaya paling popular dan digemari semua kalangan, khususnya remaja dan dewasa. Kopi merupakan salah satu sumber kafein yang tersebar luas, disamping produk lain seperti minuman energi, cocoa dan soft drink. Menurut National Coffee Association United States tahun 2011, terdapat peningkatan konsumsi kopi harian pada remaja usia 18-24 tahun, yaitu dari 13\% menjadi 36\% (National Coffee Association, 
JOURNAL OF PUBLIC HEALTH INNOVATION

VOL. 01 NO. 02 JUNI 2021

DOI: $10.34305 /$ JPHI.V1I2.304
Ciptaan disebarluaskan di bawah

Lisensi Creative Commons Atribusi-

NonKomersial-BerbagiSerupa 4.0

Internasional.
2011). Pengaruh gaya hidup dan semakin maraknya cafe serta kedai kopi memberikan kontribusi dalam peningkatan jumlah konsumen kopi.

Proporsi minum kopi di provinsi Jawa Barat menurut hasil Riskesdas 2018 menunjukkan konsumsi $>1$ cangkir per hari lebih dari data nasional sebesar 31,4\%. Konsumsi antara 1-6 kali per minggu sebesar 20,2\% dan konsumsi kurang dari sama dengan 3 kali perbulan sebesar 48,4\%.

Kabupaten Majalengka merupakan salah satu daerah di Jawa Barat yang dikenal sebagai penghasil kopi. Kopi merupakan 4 komoditas perkebunan terbesar di Majalengka. Produksi biji kopi di Majalengka sebesar 1029,88 ton pada tahun 2017 dan 1.138,26 ton pada tahun 2018. Animo minum kopi di kedai (café) di Majalengka dapat dikatakan meningkat ditandai dengan peningkatan kedai kopi dari 40 kedai di awal 2019 dan meningkat sampai 74 kedai pada tahun 2020 .

Kebiasaan minum kopi berkorelasi dengan berbagai masalah kesehatan, baik yang menguntungkan maupun merugikan. Konsumsi kafein dalam dosis rendah memang terbukti memberikan manfaat. Kafein dipercaya dapat mempengaruhi performa atau kinerja dan keadaan mental dengan mengurangi atau menghilangkan tidur (James JE \& Keane MA., 2007 dan James JE \& Rogers PJ., 2005) Polifenol dan kalium dalam kopi bersifat menurunkan tekanan darah. Polifenol menghambat terjadinya aterogenesis dan memperbaiki fungsi vaskuler, sedangkan kalium menurunkan tekanan darah sistolik dengan menghambat pelepasan renin sehingga terjadi peningkatan sekresi natrium dan air (Klag MJ, Wang NY, Meoni LA, Brancati FL, Cooper LA, Liang KY, 2010)

Sedangkan, asam klorogenat menunjukkan penundaan penyerapan absorbsi glukosa dan menghambat glukoneogenesis (Yamauchi, 2017). Hasil penelitian (Pradana DLC\& Wulandari AA., 2018) menyatakan terdapat perbedaan kadar gula darah signifikan antara pasien diabetes mellitus tipe 2 yang diberikan kopi dengan pasien diabetes mellitus tipe 2 yang tidak diberikan kopi.

Hasil penelitian (Alamsyah PR., \& Andrias DR., 2016) menunjukkan ada hubungan yang bermakna antara konsumsi teh dan konsumsi kopi dengan kejadian anemia pada lansia. Penelitian (Amami, 2017) juga menyatakan terdapat perbedaan kadar hemoglobin antara orang yang minum dan tidak minum kopi di Sampang. Pengkonsumsi kopi memiliki kadar hemoglobin yang lebih rendah dibandingkan 
JOURNAL OF PUBLIC HEALTH INNOVATION

VOL. 01 NO. 02 JUNI 2021

DOI: $10.34305 /$ JPHI.V1I2.304
Ciptaan disebarluaskan di bawah

Lisensi Creative Commons Atribusi-

NonKomersial-BerbagiSerupa 4.0

Internasional. orang yang tidak minum kopi. Kopi juga diketahui dapat meningkatkan energi ekspenditur dan aktivitas lipotik pada tubuh sehingga konsumsi jangka panjang dapat menurunkan berat badan (Ludwig IA, Clifford MN, Lean MEJ, Ashihara H, 2014).

Barista terkait dalam pekerjaannya memiliki peluang untuk lebih banyak meminum kopi dalam berbagai sajian sehingga dikhawatirkan memberikan dampak pada status kesehatannya. Hasil penelusuran di google scholar menunjukkan belum ada penelitian yang mengkaji pengaruh kopi terhadap status Kesehatan barista. Berdasarkan permasalahan tersebut peneliti merasa perlu untuk melakukan penelitian tentang "Korelasi Antara Konsumsi Kopi Dengan Tekanan Dan Gula Darah, Imt, Hb, Lama Tidur Dan Screen Time Barista Di Kabupaten Majalengka Tahun 2021".

\section{Metode}

Penelitian ini menggunakan metode penelitian kuantitatif. Menurut (Azwar, 2012) pendekatan kuantitatif yaitu penelitian yang menekankan analisisnya pada datadata numerik (angka) yang diolah dengan metode statistika. Desain penelitian yang digunakan adalah observasional analitik dengan pendekatan cross-sectional.
Penelitian observasional analitik, yaitu penelitian yang menjelaskan adanya hubungan antara variabel melalui pengujian hipotesis. Penelitian cross sectional adalah penelitian yang mengamati semua variabel pada individu secara serentak pada satu saat atau periode tertentu (Badriah, 2019).

Adapun populasi dan sampel dalam penelitian ini adalah semua barista yang terdata di Kabupaten Majalengka. Terdapat 40 barista yang saat ini tercatat menjadi anggota komunitas sehingga seluruhnya diambil menjadi sampel dan subyek penelitian ini. Teknik pengambilan sampel dalam penelitian ini bersifat sampel total (total sampling) yang merupakan suatu teknik penentuan sampel jika semua anggota populasi digunakan sebagai sampel.

Analisis data yang akan digunakan adalah analisis univariat, bivariat dan multivariat. Uji statistik yang digunakan adalah uji korelasi Rank Spearman. Uji ini digunakan pada data ordinal dan tidak berdistribusi normal. Analisis multivariat menggunakan regresi logistic berganda. Regresi logistik digunakan dalam model analisis dimana variabel dependen memiliki skala kategorik dengan dua kategori. Regresi logistik adalah regresi yang digunakan untuk menguji apakah probabilitas terjadinya 
JOURNAL OF PUBLIC HEALTH INNOVATION

VOL. 01 NO. 02 JUNI 2021

DOI: $10.34305 /$ JPHI.V1I2.304

variabel dependen dapat diprediksi dengan variabel independen.

$$
\text { Instrumen penelitian ini }
$$
menggunakan angket, sphygmomanometer dan glucometer. Angket digunakan untuk menggali informasi tentang karakteristik individu, kebiasaan minum kopi, kualitas tidur dan screen time. Sphygmomanometer digunakan untuk mengukur tekanan darah.

Hasil
Berdasarkan Tabel 1, karakteristik barista yang menjadi subyek dalam penelitian ini adalah laki-laki (95\%) dengan rata-rata usia 23,9 tahun dan bekerja selama 2,75 tahun. Sebagian besar merupakan lulusan sekolah menengah atas (SMK sebanyak 60\% dan SMA sebanyak 35\%). Sebagian besar responden minum kopi lebih dari 3 gelas perhari $(67,5 \%)$ dan memiliki kebiasaan ngemil (makan jajan) pada malam hari dan pada saat screen time $(67,5 \%)$.

Tabel 1. Karakteristik Responden

\begin{tabular}{lcc}
\hline \multicolumn{1}{c}{ Variabel } & Jumlah & Persentase \\
\hline Usia, rata-rata \pm standar deviasi & & $23,9 \pm 2,59$ \\
Lama kerja, rata-rata \pm standar deviasi & $2,75 \pm 1,43$ & \\
Jenis kelamin & 38 & 95 \\
- Laki-laki & 2 & 5 \\
- Perempuan & & \\
Tingkat Pendidikan & 14 & 35 \\
- SMA & 24 & 60 \\
- SMK & 2 & 5 \\
- Sarjana & & \\
Tingkat Konsumsi Kopi & 12 & 30 \\
- 1-3 gelas perhari & 28 & 70 \\
- > gelas perhari & & \\
Kebiasaan makan jajan (snack time) malam hari & 27 & 67,5 \\
- Ya & 13 & 32,5 \\
- Tidak & & \\
Kebiasaan makan jajan saat screen time & 27 & 67,5 \\
- Ya & 13 & 32,5 \\
- Tidak & & \\
\hline
\end{tabular}

Tabel 2. Analisis Bivariat Korelasi antara Konsumsi Kopi dengan Variabel Dependen

\begin{tabular}{lcccccc}
\hline \multirow{2}{*}{ Variabel } & \multicolumn{2}{c}{ Frekuensi minum kopi } & Total & Nilai $\boldsymbol{p}$ & $\begin{array}{c}\text { Koefisien } \\
\text { Korelasi }\end{array}$ & OR \\
\cline { 2 - 3 } & Normal & Tinggi & & & \\
\hline $\begin{array}{l}\text { Tekanan darah } \\
\text { - normal }\end{array}$ & $11(91,7)$ & $20(71,4)$ & $31(77,5)$ & 0,168 & 0,222 & 4,4 \\
- hipertensi & $1(8,3)$ & $8(28,6)$ & $9(22,5)$ & & &
\end{tabular}


Gula darah

- tinggi

- normal

$3(25))$

$3(10,7)$

$6(15)$

0,257

0,183

2,78

IMT

$9(75)$

$25(89,3)$

$34(85)$

- tinggi

$8(66,7)$

$13(46,4)$

$33(82,5)$

0,251

1,09

- rendah

$4(33,3)$

$15(53,6)$

$7(17,5)$

0,186

Hemoglobin

- normal

$10(83,3)$

$23(82,1)$

$21(52,5)$

0,93

0,014

- anemia

$2(16,7)$

$5(17,9)$

$19(47,5)$

Lama tidur

- normal

3 (25)

$19(67,9)$

$22(55)$

$9(32,1)$

18 (45)

Screen time

- normal

9 (75)

$2(7,1)$
$26(92,9)$

$1(8,3)$

$3(7,5)$

$37(92,5)$

0,899

0,021

1,18$$
\text { (1) }
$$

\section{Tabel 3. Hasil Analisis Regresi Logistik Berganda}

95\% C.I.for EXP(B)

\begin{tabular}{rrrrrrrrrr}
\cline { 7 - 8 } & & B & S.E. & Wald & Df & Sig. & $\operatorname{Exp(B)}$ & Lower & Upper \\
\hline Step 1 $^{\text {a }}$ & tensi_kat & .913 & .858 & 1.132 & 1 & .287 & 2.491 & .464 & 13.388 \\
& gula_kat & 1.479 & .890 & 2.761 & 1 & .097 & 4.387 & .767 & 25.101 \\
& IMT_kat & .346 & .775 & .199 & 1 & .656 & 1.413 & .309 & 6.454 \\
& Sleep_kat & -2.192 & .843 & 6.762 & 1 & .009 & .112 & .021 & .583
\end{tabular}

a. Variables(s) entered on step 1: tensi_kat, gula_kat, IMT_kat, Sleep_kat.

Berdasarkan tabel 2. Hasil analisis bivariat dengan uji korelasi Spearman Rank menunjukkan hanya ada satu variabel yang berhubungan yaitu lama tidur dengan nilai $\mathrm{p}=0,012$ ) dan nilai OR sebesar 0,16 ; yang artinya konsumsi kopi berisiko sebesar 0,16 untuk dapat tidur normal. Arah hubungan frekuensi minum kopi dan lama tidur negatif, sehingga dapat dikatakan semakin tinggi frekuensi minum kopi, maka waktu tidur akan semakin berkurang. Berdasarkan tabel 3. Hasil analisis menunjukkan hanya variabel lama tidur yang memiliki signifikansi kurang dari $0,05(\mathrm{p}=0,009)$.

\section{Pembahasan}


JOURNAL OF PUBLIC HEALTH INNOVATION

VOL. 01 NO. 02 JUNI 2021

DOI: $10.34305 /$ JPHI.V1I2.304

1. Korelasi konsumsi kopi dengan tekanan darah barista di Kabupaten Majalengka

Hasil analisis menunjukkan bahwa konsumsi kopi tidak berkorelasi dengan tekanan darah karena memiliki nilai signifikansi $p=0,168(p>0,05)$. Barista yang mengkonsumsi kopi dalam kategori normal, 91,7\% memiliki tekanan darah normal. Sedangkan barista yang minum kopi lebih dari $>3$ cangkir sehari, sebanyak 28,6\% memiliki tekanan darah yang tinggi.

Hasil ini sejalan dengan penelitian yang dilakukan oleh (Winata W, Vanessa A, Rico A, Rumawas ME, 2010) yang memperlihatkan tidak ada korelasi antara kebiasaan minum kopi dengan tekanan darah pada pasien berusia 20 tahun atau lebih. Penelitian eksperimen menunjukkan peningkatan tekanan darah pada konsumsi kopi bersifat akut. Sedangkan, pada peminum jangka panjang tidak terjadi peningkatan tekanan darah dan menunjukkan toleransi konsumsi kopi jangka panjang (Geleinjnse JM., 2008). Hal ini mungkin yang menjelaskan tidak adanya korelasi antara konsumsi kopi dan tekanan darah pada barista di Majalengka, selain karena usia responden yang masih muda.

2. Korelasi Konsumsi Kopi dengan Gula Darah Barista
Ciptaan disebarluaskan di bawah

Lisensi Creative Commons Atribusi-

NonKomersial-BerbagiSerupa 4.0

Internasional.
Konsumsi kopi tidak berkorelasi dengan kadar gula darah barista di Majalengka. Hasil ini ditunjukkan dengan nilai $\mathrm{p}$ sebesar $0,257(\mathrm{p}>0,05)$. Barista dengan konsumsi kopi normal sebanyak 3 orang $(25 \%)$ memiliki gula darah tinggi $(\geq$ $140 \mathrm{mmHg}$ ), sedangkan barista dengan konsumsi tinggi, 25 orang $(89,3 \%)$ memiliki kadar gula darah normal.

Penelitian lain memberikan kesimpulan yang berbeda dan menyatakan bahwa terjadi penurunan kadar gula darah pada orang sehat yang mengkonsumsi kopi (Zhang, Y., et. al, 2011). Penelitian (Ding, et. al. 2014) yang membagi responden menjadi dua kelompok peminum kopi dengan kafein dan non-kafein menunjukkan terjadi penurunan kadar gula darah yang artinya perubahan kadar gula darah tidak semata berasal dari kafein, tetapi juga komponen senyawa lain.

3. Korelasi Konsumsi Kopi dengan Indeks Massa Tubuh Barista

Hasil analisis korelasi menunjukkan bahwa konsumsi kopi tidak berkorelasi dengan indeks massa tubuh barista di Majalengka. Hasil ini ditunjukkan dengan nilai $p$ sebesar $0,251(p>0,05)$. Terdapat 15 $(53,6 \%)$ orang barista dengan tingkat konsumsi kopi yang tinggi, memiliki IMT yang lebih rendah. 
JOURNAL OF PUBLIC HEALTH INNOVATION

VOL. 01 NO. 02 JUNI 2021

DOI: $10.34305 /$ JPHI.V1I2.304
Ciptaan disebarluaskan di bawah

Lisensi Creative Commons Atribusi-

NonKomersial-BerbagiSerupa 4.0

Internasional.
Penelitian ini sejalan dengan penelitian (Riawan, 2018) yang menyimpulkan bahwa konsumsi kopi tidak berdampak pada orang dengan berat badan normal. Akan tetapi, pada orang yang mempunyai berat badan berlebih atau obesitas, dengan mengkonsumsi kopi pada pagi hari sekitar $6 \mathrm{mg}$ kafein/kg (setara dua cangkir kopi), maka secara signifikan dapat menurunkan asupan makan dan energi yang akan mempengaruhi status gizi.

Hasil penelitian ini berbeda dengan kesimpulan yang disampaikan oleh Siagia dalam (Riawan, 2018) jika mengkonsumsi kopi pada pagi hari akan mengurangi rasa lapar pada siang hari karena adanya hormon leptin yang dilepaskan setelah makan. Saat sarapan pagi, akan memicu pelepasan leptin yang membuat tubuh merasa tidak lapar.

4. Korelasi Konsumsi Kopi dengan Kadar Hemoglobin Barista

Hasil analisis menunjukkan sebanyak 5 orang $(17,9 \%)$ barista dengan konsumsi kopi yang tinggi, menderita anemia. Hasil analisis menyatakan bahwa konsumsi kopi tidak berkorelasi dengan kadar anemia karena memiliki nilai $p=0,93$ $(\mathrm{p}>0,05)$.

Hasil penelitian (Alamsyah PR., \& Andrias DR., 2016) menunjukkan ada hubungan yang bermakna antara konsumsi teh dan konsumsi kopi dengan kejadian anemia pada lansia. Lansia yang anemia mengkonsumsi kopi 7 kali perminggu dan lansia yang tidak anemia konsumsi 3 kali per minggu. Konsumsi teh pada lansia anemia 12 kali per minggu sedangkan lansia yang tidak anemia mengkonsumsi teh 5 kali per minggu.

Hasil penelitian ini tidak sejalan dengan penelitian (Maulidia, A., \& Jatmiko, 2021) yang menyatakan bahwa kafein dalam kopi berhubungan dengan kadar $\mathrm{Hb}$ pada hewan coba tikus. Minum teh, kopi, dan susu setelah makan akan membuat tubuh kehilangan Fe yang berakibat pada anemia. Kandungan tanin dan fitat pada teh dan kopi serta kalsium dan fosfor pada susu dapat mengikat zat besi sehingga sulit untuk diserap.

5. Korelasi Konsumsi Kopi dengan Lama Tidur Barista

Hasil analisis menunjukkan bahwa konsumsi kopi berkorelasi negatif dengan lama tidur yang dibuktikan dengan nilai $p=0,012(p<0,05)$. Artinya, semakin banyak jumlah kopi yang dikonsumsi, maka lama tidur akan semakin berkurang. Kekuatan hubungan antara konsumsi kopi dan tekanan darah sebesar $(-0,395)$ dan berada pada kategori sedang $(0,25-0,50)$. Odd ratio dari hubungan ini sebesar 0,16 yang berarti 
JOURNAL OF PUBLIC HEALTH INNOVATION

VOL. 01 NO. 02 JUNI 2021

DOI: $10.34305 /$ JPHI.V1I2.304
Ciptaan disebarluaskan di bawah

Lisensi Creative Commons Atribusi-

NonKomersial-BerbagiSerupa 4.0

Internasional. semakin banyak kopi yang dikonsumsi, maka risiko untuk dapat tidur normal hanya 0,16 kali (semakin rendah karena kurang dari 1).

Jika dilihat dari data deskriptif menunjukkan rata-rata waktu tidur normal ( 8 jam), akan tetapi jam tidur barista tidak menentu dan terlalu larut malam. Sebanyak 9 orang $(32,1 \%)$ barista dengan tingkat konsumsi kopi tinggi memiliki waktu tidur kurang.

Hasil penelitian ini sesuai dengan penelitian yang dilakukan oleh (Ammon HPT., 2005). Kopi mempunyai kaitan dengan lama tidur yang rendah. Penelitian menunjukkan bahwa tingginya konsumsi kafein dapat membuat seseorang susah untuk tidur. Hal ini disebabkan kandungan pada kopi yaitu kafein yang dapat meningkatkan kewaspadaan, meningkatkan performa kerja dan menurunkan rasa kantuk saat lama tidur menurun.

6. Korelasi Konsumsi Kopi dengan Screen Time Barista

Sebanyak 26 orang $(92,9 \%)$ barista dengan tingkat konsumsi kopi tinggi memiliki waktu screen time lama. Hasil analisis korelasi menunjukkan bahwa konsumsi kopi tidak berkorelasi dengan screen time barista di Majalengka. Hasil ini ditunjukkan dengan nilai p sebesar 0,899 (p>
0,05). Waktu screen time erat kaitannya dengan kualitas tidur. Waktu tidur yang kurang dikompensasi menjadi kegiatan screen time.

Penelitian (Yland J, Guan S, Emanuele E, 2015) menyimpulkan anak dengan eksposur monitor selama 2 jam dalam bentuk chatting di komputer akan mengurangi durasi tidur sebanyak 16 menit dan jika ditambahkan dengan 2 jam menonton televisi atau film akan membuat tambahan durasi tidur sebanyak 11 menit. Sedangkan, kegiatan seperti bermain video games dan bekerja di depan komputer tidak terbukti membuat efek apapun terhadap durasi tidur.

Penelitian yang dilakukan oleh (Ahluwalia, N; Frenk, SM; Quan, 2018) menggunakan data National Health and Nutrition Examination Survey (NHNES) 2007-2012 menunjukkan bahwa menonton TV berhubungan dengan konsumsi kafein pada anak usia sekolah di Amerika (6-11 tahun).

7. Model Korelasi Regresi Logistik Berganda Pada Konsumsi Kopi

Semua variabel yang memiliki nilai $\mathrm{p}<0,25$ kemudian dianalisis secara bersamasama terhadap konsumsi kopi, yaitu tekanan darah, gula darah, IMT dan lama tidur. yang digunakan adalah regresi logistik berganda. 
JOURNAL OF PUBLIC HEALTH INNOVATION

VOL. 01 NO. 02 JUNI 2021

DOI: $10.34305 /$ JPHI.V1I2.304
Ciptaan disebarluaskan di bawah

Lisensi Creative Commons Atribusi-

NonKomersial-BerbagiSerupa 4.0

Internasional.
Hasil dari pemodelan menunjukkan bahwa konsumsi kopi mempengaruhi lama tidur yang dikontrol dengan variabel tekanan darah, kadar gula darah dan indeks massa tubuh barista di Kabupaten Majalengka.

Variabel yang berkorelasi secara signifikan dengan konsumsi kopi adalah lama tidur, sehingga untuk mendapatkan model yang tepat harus mengeluarkan satupersatu variabel selain lama tidur. Akan tetapi, ketiga variabel yang lain tetap ada pada bentuk model karena setelah dikeluarkan, perubahan OR variabel lain > $10 \%$ dan berhak dimasukkan lagi dalam model.

\section{Kesimpulan}

Berdasarkan hasil analisis dalam penelitian ini dapat disimpulkan bahwa:

1. Responden rata-rata meminum kopi sebanyak 4 gelas perhari, memiliki tekanan darah sistolik $117 \mathrm{mmHg}$, diastolik 77,75 mmHg, kadar gula darah sebesar 115,5 mg/dl dan kadar Hemoglobin 13,8 mg/dl. Semua responden memiliki status gizi baik, waktu tidur yang cukup (8,74 jam), dan screen time yang berlebih $(8,1 \mathrm{jam})$.

2. Konsumsi kopi tidak berkorelasi dengan tekanan darah barista di Kabupaten Majalengka.
3. Konsumsi kopi tidak berkorelasi dengan kadar gula darah barista di Kabupaten Majalengka.

4. Konsumsi kopi tidak berkorelasi dengan indeks massa tubuh barista di Kabupaten Majalengka

5. Konsumsi kopi tidak berkorelasi dengan kadar $\mathrm{Hb}$ barista di Kabupaten Majalengka

6. Konsumsi kopi berkorelasi negatif dengan lama tidur barista di Kabupaten Majalengka

7. Konsumsi kopi tidak berkorelasi dengan screen time barista di Kabupaten Majalengka

8. Konsumsi kopi mempengaruhi lama tidur yang dikontrol dengan variabel tekanan darah, kadar gula darah dan indeks massa tubuh barista di Kabupaten Majalengka.

\section{Saran}

Perlu dilakukan pemeriksaan terhadap beberapa indikator status kesehatan seperti tekanan darah dan pemeriksaan darah diantaranya kadar gula, lemak, hemoglobin, LDL dan HDL sebagai skrining penyakit sindrom metabolik dan kardiovaskuler.

Pemilik kedai perlu memperhatikan jam operasional kedai sehingga tidak tutup terlalu larut. Meskipun memiliki waktu tidur yang cukup, akan tetapi barista melewatkan 
JOURNAL OF PUBLIC HEALTH INNOVATION

VOL. 01 NO. 02 JUNI 2021

DOI: $10.34305 /$ JPHI.V1I2.304

waktu ideal dan mulai tidur setelah tengah malam

\section{Daftar Pustaka}

Ahluwalia, N; Frenk, SM; Quan, S. (2018) 'Screen time behaviours and caffeine intake in US children: findings from the cross-sectional National Health and Nutrition Examination Survey (NHANES)', BMJ Paediatrics Open 2018;2: e000258.

Alamsyah PR., \& Andrias DR. (2016) 'Hubungan Kecukupan Zat Gizi dan Konsumsi Makanan Penghambat Zat Besi dengan Kejadian Anemia pada Lansia', Skripsi. Universitas Airlangga. Surabaya: Naskah tidak diterbitkan.

Amami, M. (2017) 'Perbandingan Kadar Hemoglobin pada Pengkonsumsi Kopi dan Bukan Pengkonsumsi Kopi di Kabupaten Sampang', Karya Tulis Ilmiah, Universitas Muhammadiyah Surabaya Program Studi Analis Kesehatan, Surabaya: Naskah tidak dipublikasikan.

Ammon HPT. (2005) 'Biochemical of Caffeine Tolerance. Arch Pharm', 324 , pp. 261-267.

Azwar (2012) Metode Penelitian. Yogyakarta: Pustaka pelajar.

Badriah (2019) Metodologi penelitian ilmuilmu kesehatan. Bandung: Multazam.

Ding, M., Bhupathiraju, S.N., Chen, M., Van Dam, R.M., Hu, F. B. (2014) 'Caffeinated and decaffeinated coffee consumption and risk of type 2 diabetes: a systematic review and a
Ciptaan disebarluaskan di bawah

Lisensi Creative Commons Atribusi-

NonKomersial-BerbagiSerupa 4.0

Internasional.

dose-response meta-analysis.', Diabetes Care, 37(2), pp. 569-86.

Geleinjnse JM. (2008) 'Habitual coffee consumption and blood pressure: an epidemiological perspective.', Vascular health and Risk Management, 4(5), pp. 963-70.

James JE \& Keane MA. (2007) 'Caffeine, sleep and wakefulness: implications of new understand about withdrawal reversal', Human Psychopharmacology, 22, pp. 549-58.

James JE \& Rogers PJ. (2005) 'Effects of caffeine on performance and mood: withdrawal reversal is the most plausible explanation.', Psychopharmacology, (110), pp. 4552.

Klag MJ, Wang NY, Meoni LA, Brancati FL, Cooper LA, Liang KY, et al. (2010) 'Coffee Intake and Hypertension.', Arch Intern Med, (162), pp. 657-662.

Ludwig IA, Clifford MN, Lean MEJ,

Ashihara H, C. A. (2014) 'Coffee: biochemistry and potential impact on health.', Food Func, 5(8), pp. 1695717.

Maulidia, A., \& Jatmiko, S. W. (2021) 'Pengaruh Kopi terhadap Parameter Darah pada Tikus Putih Galur Wistar Diabetik yang Diinduksi Aloksan', Jurnal Kedokteran dan Kesehatan, 17(1), pp. 35-43.

National Coffee Association (2011) 'Nation of coffee drinkers, across every demographic'. Available at: http://ctbythenumbers.info/2013/11/2 6/nation-coffee-drinkers-across- 
every-demographic/-diakses tanggal 14

April

2017.http://ctbythenumbers.info/2013

/11/26/nation-coffee-drinkers-across-

every-demographic/-diakses tanggal 14 April 2017.

Pradana DLC\& Wulandari AA. (2018) 'Dampak Konsumsi Kopi Arabika Espresso dalam Menurunkan Kadar Glukosa Darah pada Pasien Diabetes Melitus Tipe-2', Jurnal Insan Farmasi Indonesia, 2(1), pp. 26-33.

Riawan, C. (2018) 'Hubungan Asupan Kafein Terhadap Asupan Makan dan Status Gizi Pada Mahasiswa Universitas Brawijaya Malang (Doctoral dissertation, Universitas Brawijaya)'.

Winata W, Vanessa A, Rico A, Rumawas ME, K. V. (2010) 'Hubungan antara Kebiasaan Konsumsi Kopi dan
Tekanan darah pada Pasien Berumur 20 atau Lebih', Ebers Papyrus, 16(2), pp. 93-104.

Yamauchi, R. et al. (2017) 'Coffee and Caffeine Ameliorate Hyperglycemia, Fatty Liver, and Inflammatory Adipocytokine', Journal of Agricultural and Food Chemistry.

Yland J, Guan S, Emanuele E, H. L. (2015) 'Interactive vs passive screen time and nighttime sleep duration among school aged children', Sleep Health, 1(3), pp. 191-196.

Zhang, Y., Lee, E.T., Cowan, L.D., Fabsitz, R.R., Howard, B. V. (2011) 'Coffee consumption and the incidence of type 2 diabetes in men and women with glucose tolerance: The Strong Heart Study', National Institutes Of Health,Jun, 21(6), pp. 418-423. 